\title{
The Influence of Experiential Marketing And Service Quality For being Reasonability of Customers Loyality Forming (Case Study of Beauty Saloon of London Beauty Center " LBC")
}

\author{
Ria Lestari Pangastuti \\ UniversitasKadiri - Kota Kediri \\ ria_lestari@unik-kediri.ac.id
}

\begin{abstract}
This research is testing the influence of Experiential Marketing and Service Quality for being reasonability of Customers Loyality Forming. The sample is 66 person. The analysis technique used is path analysis by using smart pls. The result shows from four variabels, the biggest contribution of experiential marketing is ACT with the standardized coefisien 0.884 , it means there is influence of experiental marketing about $88.4 \%$. This means the increasing of ACT will make the increasing of Experiental marketing $88.4 \%$. The other variable which influenced is quality toward the loyality.The quality is composed by Assurance, Empathy, Reliability, Responsiveness, and Tangible. The indicator which has the biggest contribution is assurance with the value indicator of coeficient standarized 0.722 .
\end{abstract}

Key Word : Experiential Marketing, service quality, customer loyality.

\begin{abstract}
Abstrak
Penelitian ini menguji pengaruh Pengaruh Experiential Marketing Dan Kualitas Layanan Yang Dipertimbangkan Dalam Pembentukan Loyalitas Konsumen. Sampel dalam penelitian ini sebanyak 66 orang. Tehnik analisis yang digunakan dalam penelitian ini adalah tehnik analisis menggunakan analisis jalur dengan menggunakan alat analisis smart pls. Hasil dari penelitian ini menunjukan dari ke empat variabel ini, yang memiliki kontrobusi paling besar terhadap experiental marketing adalah ACT dengan nilai standardized koefisien sebesar 0.884 dimana nilai ini memiliki arti bahwa perubahan pada ACT akan berpengaruh terhadap perubahan experiental marketing sekitar $88.4 \%$. Nilai ini juga dapat dimaknai kenaikan pada ACT akan berdampak pada kenaikan Experiental marketing sebesar 88.4\%. Variabel kualitas juga memiliki pengaruh yang signifikan terhadap loyalitas. Kualitas disusun oleh Assurance, Empathy, Reliability, Responsiveness, dan Tangible. Indikator yang memiliki kontribusi paling besar dalam menyusun kualitas adalah pada Assurance dengan nilai standardized koefisien sebesar 0.722 .
\end{abstract}

Kata Kunci : Experiential Marketing, Kualitas Layanan, Loyalitas Konsumen. 


\section{PENDAHULUAN}

\section{Latar Belakang Masalah}

Menurut Dharmmesta, Hou, dan Agung dalam Karnani (2000) perilakukonsumen wanita abad 21 konsumen akan semakin mengalami perkembangan, hal inidipengaruhi oleh beberapa faktor, yaitu: (1) Angkatan kerja dengan pendidikan yanglebih tinggi yang menyebabkan daya beli lebih tinggi, (2) Akses informasi yang lebihbanyak dan mudah sehingga membentuk wawasan yang lebih kaya, (3) Karir yangmembentuk perilaku beli berorientasi pada tempat kerja dan kepraktisan, serta (4)Kehidupan kosmopolitan yang membentuk perilaku mengikuti gaya barat atauinternasional. Kemudian menurut Dharmmesta dalam Karnani (2000) salah satu orientasi gaya hidup dimasa depan adalah adanya kecenderungan untuk meningkatkan diri secara fisik atau ingin berpenampilan yang lebih baik.

Melihat perubahan perilaku konsumen ini salah satu industri yang berkembang secara pesat adalah industri kecantikan, ini dapat dilihat dari menjamurnya klinik kecantikan di Indonesia umumnya dan khususnya di kediri. Cantik saat ini telah menjadi kebutuhan kaum wanita. Kaum wanita menggambarkan kecantikan dengan ukuran keindahan penampilan yang terdiri dari wajah dan tubuh yang sehat, putih, santik dan berseri, karena saat ini penampilan dianggap sebagai salah satu aset kaum wanita yang harus dijaga untuk meningkatkan rasa percaya diri.

Kota Kediri merupakan salah satu kota yang sedang berkembang di kota ini sekarang sudah banyak sekali dibuka klinik-klinik kecantikan antara lain : Natasha, Larissa, London Beauty Center (LBC), DMR, Dermafit, Kirana Estetik Center, Madani, Navagreen dan masih banyak lagi. Klinik-klinik ini menyediakan berbagaimacam perawatan sesuai dengan kebutuhan kaum wanita masa kini mulai dari harga untuk kalangan mengengah hingga kalangan atas ada disini. Dengan menjamurnya klinik kecantikan di kota kediri menyebabkan persaingan ketat antar klinik kecantikan tersebut.

Dalam peneilitian ini peneliti meneliti tentang salah satunya adalah klinik kencantikan “London Beauty Center (LBC)” yang merupakan klinik terpercaya yang ada sejak tahun 1998 dan terpusat di kota Yogyakarta. Fokus utama “ London Beauty Center (LBC)" adalah bagaimana klinik kecantikan ini dapat merebut pangsa pasar dari pesaingnya. Dengan adanya kondisi ini, maka klinik kecantikan “ London Beauty 
Center (LBC)" harus siap untuk menyesuaikan diri dengan adanya perubahan yang ada pada pelanggan dari berbagai sisi. Apabila hal ini dapat terpenuhi maka tujuan untuk menguasai pangsa pasar akan tercapai.

Loyalitas dari konsumen dianggap sebagai faktor utama pendukung siklus hidup dari sebuah perusahaan, sehingga penting bagi LBC untuk merencanakan agar konsumen dalam kurun waktu yang panjang bisa loyal terhadap perusahaan. Menurut Kotler dan Keller (2012:138) Loyalitas adalah komitmen yang dipegang secara mendalam untuk membeli atau mendukung kembali produk atau jasa yang disukai di masa depan meski pengaruh situasi dan usaha pemasaran berpotensi menyebabkan pelanggan beralih.

Ada berbagai strategi yang bisa dipakai untuk menyikapi perubahan yang terjadi di pasar demi mempertahankan loyalitas konsumen, salah satunya adalah dengan menggunakan Experiential marketing. Inti dari experiential marketing adalah untu kmembangun hubungan yang langgeng dengan pelanggan. Hal ini juga diperkuat pendapat (Schmitt dalam Hermawan Kertajaya 2006) dimana experiential marketing dapat dihadirkan melalui limaunsur yaitu sense, feel, think, act, dan relate. Dengan begitu experiential marketing harus dipastikan mampu memberikan hubungan yang signifikan dengan loyalitas konsumen.

Selain bergantung dari bagaimana cara penerapan experientialmarketing, kualitas layanan juga menjadi pendukung utama untuk mendapatkan loyalitas konsumen. Kualitas layanan sering kali digunakan oleh konsumen sebagai salah satu bahan pertimbangan dalam memutuskan untuk menggunakan kembali produk atau jasa yang ditawarkan oleh pemasar. Jika klinik kecantikan "LBC” bisa memberikan kualitas pelayanan yang baik terhadap konsumennya, maka dapat dipastikan bahwa kualitas pelayanan dapat mempengaruhi loyalitas konsumen.

Berdasarkan uraian diatas maka peneliti akan meneliti tentang "Pengaruh Experiential Marketing Dan Kualitas Pelayanan Yang Dipertimbangkan Dalam Pembentukan Loyalitas Konsumen Pada Klinik Kecantikan "LBC”.

\section{Rumusan Masalah}

Rumusan masalah dalam penelitian ini berdasarkan uraian latar belakang diatas adalah sebagai berikut : 
1. Apakah Experiential Marketing dan Kualitas Pelayanan mempunyai pengaruh secara parsial terhadap Loyalitas Konsumen?

2. Apakah Experiential Marketing dan Kualitas Pelayanan mempunyai pengaruh secara simultan terhadap Loyalitas Konsumen?

\section{Tujuan Penelitian}

Tujuan dari penelitian ini adalah untuk mengetahui :

1. Untuk mengetahui pengaruhsecara parsial antara variabelExperential Marketing dan Kualitas Pelayanan terhadap Loyalitas Konsumen

2. Untuk mengetahui pengaruhsecara simultan antara variabelExperential Marketing dan Kualitas Pelayanan terhadap Loyalitas Konsumen

\section{TINJAUAN PUSTAKA}

\section{Penelitian Terdahulu}

Reymond Setiabudi Hadiwidjaja dan Diah DharmayantiTahun 2015dalam penelitianyang berjudul "Analisis Hubungan Experiential Marketing, Kepuasan Pelanggan, Loyalitas Pelanggan Starbucks Coffee Di Surabaya Town Square “ menyatakan bahwa experiential marketing memiliki pengaruh yang positif dan signifikan terhadap kepuasan pelanggan, begitupula experiential marketing terhadap loyalitas pelanggan juga memiliki pengaruh positif dan signifikan. Sedangkan variabel kepuasan pelanggan terhadap loyalitas pelanggan juga terdapat pengaruh positif dan signifikan jadi ketika tingkat kepuasan pelanggan semakin tinggi, maka loyalitas pelanggan starbucks coffee juga semakin tinggi pula.

Novita Ekasari Tahun 2015dalam penelitian yang berjudul“" Pengaruh Experiential Marketing Terhadap LoyalitasPelanggan Klinik Perawatan Kulit Natasha Kota Jambi “. Hasil penelitian menunjukkan bahwa 5 unsur experiential marketing yang terdiri dari sense, feel, think, act dan relate mempunyai pengaruh positif dan signifikan terhadap loyalitas pelanggan, sedangkan dari ke 5 unsur experiential marketing tadi feel merupakan unsur yang memiliki nilai signifikansi palinh besar yaitu 4,542 .

Dita Prasetya Tahun2015dalam penelitian yang berjudul“" Pengaruh strategi experiential marketing dan kepuasan pelanggan terhadap kepuasan pelanggan dan 
loyalitas “. Hasil penelitian ini menunjukkan bahwa experiential marketing berpengaruh signifikan terhadap kepuasan pelanggan, sedangkan kualitas pelayanan berpengaruh signifikan terhadap kepuasan pelanggan. Untuk variabel experiential marketing secaratidak berpengaruh signifikan terhadap loyalitas, sedangkan untuk experiential marketing berpengaruh signifikan.

Lee, Hsiao, dan Yang pada tahun 2010 dalam penelitiannya yang berjudul "The Study Of The Relationship Among Experiential Marketing, Service Quality, Customer Satisfaction And Customer Loyalty"dengan objek penelitian adalah pelanggan dari sHopping malls yang ada di Taiwan. Dengan menggunakan alat analisis convenient sampling, demographic variabels, factor analysis, reliability analysis, T-test, dan multiple regression analysis mereka menemukan ada 4 tipe pelanggan. Penelitian tersebut menyebutkan bahwa experiential 22 marketing memiliki pengaruh yang positif terhadap kepuasan pelanggan. Kualitas pelayanan secara parsial memiliki pengaruh positif terhadap kepuasan pelanggan. Kepuasan pelanggan memiliki pengaruh yang positif terhadap loyalitas pelanggan. Kualitas pelayanan memiliki pengaruh positif terhadap loyalitas pelanggan.

\section{Experiential marketing}

Schmitt (1999)menyatakan bahwa experience adalah pengalaman dari peristiwa pribadiyang terjadi sebagai tanggapan atas beberapa stimulus atau ransangan.Pengertian dari experiential marketing menurut Schmitt (1999)adalah cara untuk menciptakan pengalaman yang akan dirasakan olehpelanggan ketika menggunakan produk atau jasa melalui panca indera(sense), pengalaman afektif (feel), pengalaman berpikir secara kreatif(think), pengalaman pelanggan yang berhubungan dengan tubuh secarafisik, dengan perilaku dan gaya hidup, serta dengan pengalaman - pengalamansebagai hasil dari interaksi dengan orang lain (act), jugamenciptakan pengalaman yang terhubung dengan keadaan sosial, gayahidup, dan budaya yang dapat merefleksikan merek tersebut yangmerupakan pengembangan dari sense, feel, think, dan act (relate)(Schmitt,1999). Experiential marketing adalah pengembangan dari strategipemasaran tradisional, perkembangan experiential marketing dipengaruhioleh faktor teknologi informasi dan komunikasi (Schmitt, 1999).Perbedaan antara pemasaran tradisional dan pemasaran 
berbasisexperiential dideskripsikan melalui karakteristik utama dari experiential marketing yang diadaptasi dari pendapat Schmitt (1999) sebagai berikut :

1. Fokus pada pengalaman pelanggan

Pengalaman terjadi ketika seseorang berjumpa dengan suatusituasi. Pengalaman merupakan stimulasi terhadap panca indera,perasaan, dan pikiran seseorang. Maka, pengalaman memberikan nilaisensorik, emosional, kognitif, perilaku, dan relasional yangmenggantikan nilai fungsional.

2. Situasi konsumsi sebagai pengalaman Holistik

Fokus pada produk apa yang sesuai dengan situasi konsumsenserta bagaimana produk, kemasan, dan media komunikasi dapatmeningkatkan pengalaman pelanggan. Sehingga dapat disimpulkanbahwa periode pasca pembelian merupakan hal yang terpenting dalamexperiential marketing.

3. Memahami pendorong rasional dan emosional pelanggan

Pelanggan tidak hanya dimotivasi oleh pemikiran rasionaldalam pengambilan keputusan pembelian, tetapi juga dipengaruhi olehemosi karena pelanggan ingin mendapatkan pengalaman yangmenyenangkan.

\section{Dimensi Experiential Marketing}

\section{Sense}

Sense adalah usaha penciptaan suatu pengalaman yangberkaitan dengan panca indera melalui penglihatan, suara, sentuhan,rasa, dan bau. Sense marketing digunakan untuk membedakanperusahaan dan produk, memotivasi pelanggan, serta memberikannilai tambah bagi produk. Kunci sukses dalam menciptakanpengalaman panca indera (sense) adalah dengan menjamin konsistensidan menciptakan keragaman.

2. Feel

Perusahaan menggunakan strategi feel experience untukmemberikan pengaruh merek kepada pelanggan melalui komunikasi(iklan), iklan yang bersifat feel good digunakan merangsan emosionalpelanggan dengan produk atau jasa dan memberikan stimulus kepadapelanggan untuk bereaksi terhadap iklan atau pesan tersebut, produk(identitas, kemasan, dan isi), lingkungan, web-sites, atau orang-orangyang menawarkan produk (Schmitt, 1999). Feel experience padatingkat yang lebih tinggi 
adalah affective experience yangmenggerakkan stimulus emotion dan moods (Schmitt, 1999).

3. Think

Think membuat pelanggan melakukan interaksi secara creativedan cognitive. Tujuan dari strategi think adalah untuk mendorongpelanggan sehingga tertarik dan berpikir secara kreatif (Schmitt,1999).

4. Act

Act experience didesain untuk menciptakan pengalamanpelanggan yang berhubungan dengan tubuh secara fisik, pada perilakudan gaya hidup jangka panjang serta pengalaman-pengalaman yangterjadi sebagai hasil dari interaksi dengan orang lain (Schmitt, 1999).

5. Relate

Relate experience bertujuan untuk menghubungkan pelanggantersebut dengan budaya dan lingkungan sosial (masyarakat). Relateditujukan untuk membentuk self improvement, status socio economic,dan image (Schmitt, 1999).

\section{Kualitas Pelayanan}

Kualitas pelayanan adalah salah satu faktor pembentuk loyalitas pelanggan. Apabila kualitas yang diberikan kepada pelanggan baik, maka fokus perusahaan untuk menguasai pasar akan terwujud. Kualitas pelayanan sering diartikan sebagai perbandinganantara layanan yang diharapkan dengan layanan yang diterima secaranyata. Layanan (service) adalah sebuah kegiatan, manfaat, atau kepuasanuntuk diberikan yang pada dasarnya tidak berwujud dan tidakmengakibatkan kepemilikan apapun (Kotler dan Amstrong, 2012).Parasuraman (2001:26) mengemukakan konsep kualitas layanan yang berkaitan dengan kepuasan ditentukan oleh lima unsur yang biasa dikenal dengan istilah kualitas layanan "RATER" (responsiveness, assurance, tangible, empathy dan reliability). Konsep kualitas layananRATER intinya adalah membentuk sikap dan perilaku dari pengembang pelayanan untuk memberikan bentuk pelayanan yang kuat dan mendasar, agar mendapat penilaian sesuai dengan kualitas layanan yang diterima. Konsep RATER adalah sebagai berikut : 
a. Responsiveness

Indikator untuk mengetahui seberapa baik perusahaan berupayauntuk membantu dan memberikan jasa yang cepat kepadapelanggan.

b. Assurance

Indikator untuk mengetahui seberapa baik pengetahuan,keramahan, dan kemampuan para pekerja melakukan tugas secaraspontan dan menjamin kinerja yang baik sehingga menimbulkankepercayaan dan keyakinan pelanggan.

c. Tangible

Indikator untuk mengetahui seberapa baik penampilan fisik yangdapat diandalkan.

d. Empathy

Indikator untuk mengetahui seberapa baik perusahaan memahamikeinginan pelanggan dan memberikan sentuhan/perhatian secaraikhlas kepada setiap pelanggan.

e. Reliability

Indikator untuk mengetahui seberapa baik kemampuan untukmemberikan jasa sesuai dengan yang dijanjikan dengan akurat danterpercaya sesuai harapan pelanggan.

\section{Loyalitas (Y)}

Loyalitas menurut Kotler dan Keller (2012) adalah komitmen untuk membeli kembali atau mendukung kembali produk atau jasa yang disukai pada masa yang akan datang. Milligan dan Smith dalam Obonyo (2011) menuturkan bahwa loyalitas memiliki 3 dimensi yaitu.

a. Behavioral loyalty

Behavioral loyalty diukur berdasarkan frekuensi pembelian dari produk dan servis yang diberikan oleh perusahaan.

b. Attitudinal loyalty

Attitudinal loyalty diukur berdasarkan pembelian ulang yang dilakukan oleh pelanggan.

c. Cognitive loyalty

Cognitive loyalty diukur berdasarkan pemikiran pelanggan terhadap produk. 


\section{Kerangka berpikir}

\section{Gambar 1 : Kerangka Penelitian}

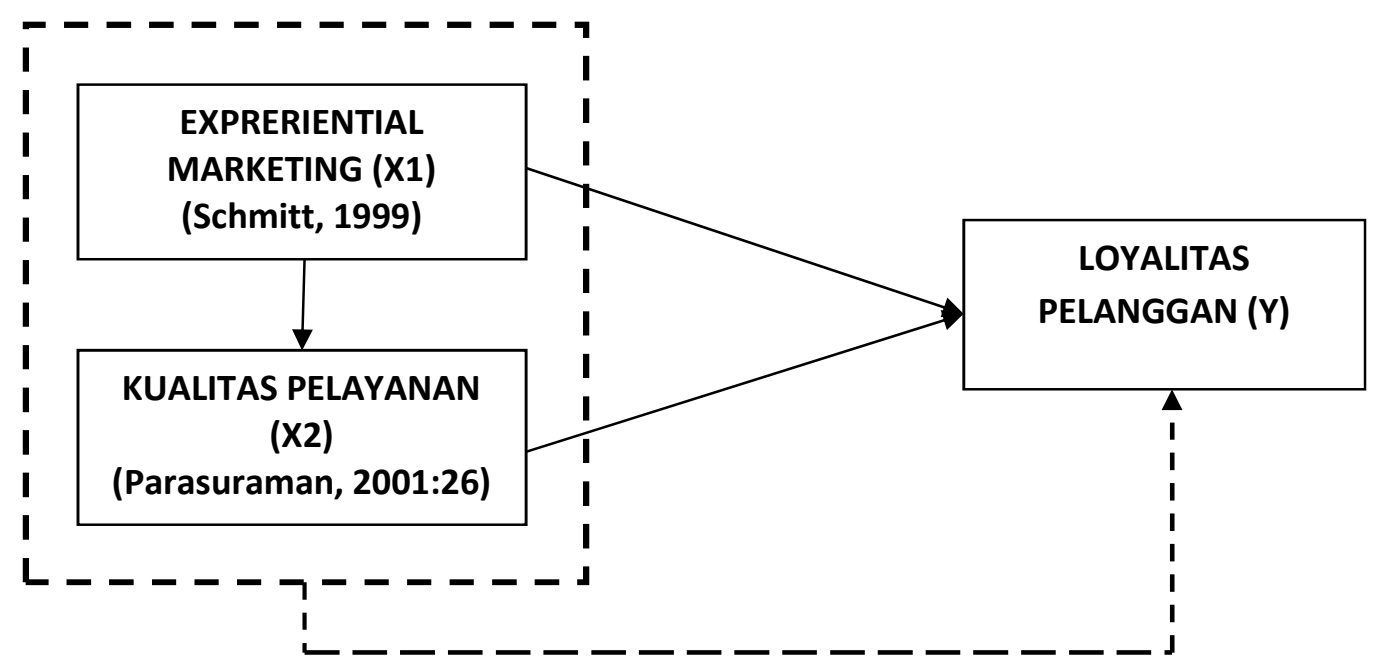

\section{Hipotesis}

Hipotesis dalam penelitian ini adalah :

H1 : variabel experiental marketing dan kualitas pelayanan berpengaruh secara simultan terhadap loyalitas pelanggan

H2 : variabel experiental marketing dan kualitas pelayanan berpengaruh secara parsial terhadap loyalitas pelanggan

\section{METODE PENELITIAN}

\section{Jenis Penelitian}

Jenis Penelitian yang digunakan dalam penelitian ini adalaheksplantory research, yang bertujuan untuk mengetahui besar kecilnya pengaruh antara variabel independen dan variabel dependen yang diteliti.

\section{Populasi Dan Sampel}

Populasi dalam penelitian ini adalah seluruh konsumen yang melakukan perawatan di klinik London Beauty Center " LBC " yang jumlahnya kurang lebih 660 orang perbulan. Dari jumlah populasi sebanyak 660 orang ini akan diambil sampel dengan perhitungan Tabel Yount (1999) sebagai berikut : 
Tabel 1 : Tabel Yount

\begin{tabular}{|c|c|}
\hline Besaran Populasi & Besar Sampel \\
\hline $0-100$ & $100 \%$ \\
\hline $101-1.000$ & $10 \%$ \\
\hline $1.001-5.000$ & $5 \%$ \\
\hline $5.001-10.000$ & $3 \%$ \\
\hline$>10.000$ & $1 \%$ \\
\hline
\end{tabular}

Bila dilihat dari tabel diatas maka sampel dalam penelitian ini adalah :

$660 \times 10 \%=66$ orang

\section{Teknik Pengambilan Sampel}

Teknik penarikan sampel dalam penelitian ini menggunakan non probability sampling, yaitu teknik yang tidak memberikan peluang atau kesempatan sama bagi setiap unsur atau anggota populasi untuk dipilih menjadi sampel.

Teknik penentuan sampel yang digunakan adalah accidental sampling atau convenience sampling, dengan ketentuan calon responden yang dipilih adalah pelanggan dari klinik London Beauty Center "LBC" yang sedang melakukan perawatan ataupun yang pernah melakukan perawatan dalam kurun waktu 3 bulan terakhir.

\section{Definisi Operasional}

Tabel 2 : Definisi Operasional

\begin{tabular}{|c|c|c|}
\hline KONSEP & DEFINISI & INDIKATOR \\
\hline $\begin{array}{l}\text { Experiential } \\
\text { Marketing Schmitt } \\
\text { dalam Obonyo } \\
(2011)\end{array}$ & \begin{tabular}{lr} 
cara untuk & \multicolumn{2}{r}{ menciptakan } \\
pengalaman yang akan & akan \\
dirasakan olehpelanggan \\
ketika menggunakan produk \\
atau jasa melalui panca \\
indera(sense), pengalaman \\
afektif (feel), pengalaman \\
berpikir secara kreatif(think), \\
pengalaman pelanggan yang \\
berhubungan dengan tubuh \\
secarafisik, dengan perilaku \\
dan gaya hidup, serta dengan \\
pengalaman \\
pengalamansebagai hasil dari \\
interaksi dengan orang lain
\end{tabular} & 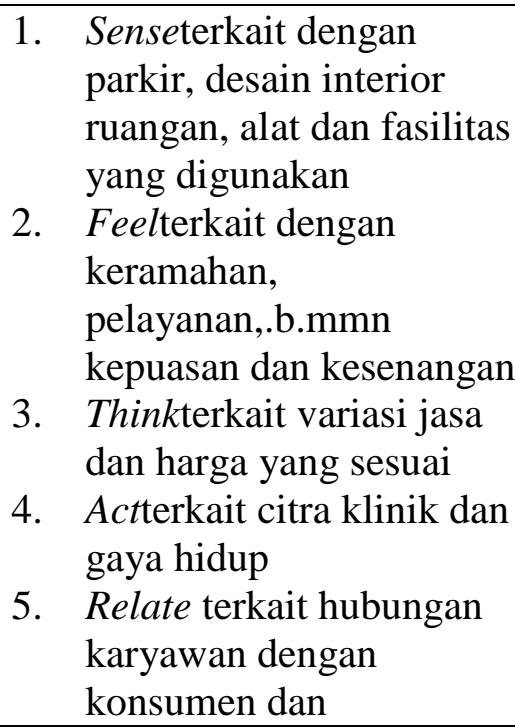 \\
\hline
\end{tabular}




\begin{tabular}{|c|c|c|}
\hline & $\begin{array}{l}\text { (act), jugamenciptakan } \\
\text { pengalaman yang terhubung } \\
\text { dengan keadaan sosial, } \\
\text { gayahidup, dan budaya yang } \\
\text { dapat merefleksikan merek } \\
\text { tersebut yangmerupakan } \\
\text { pengembangan dari sense, } \\
\text { feel, think, act dan relate }\end{array}$ & $\begin{array}{l}\text { penggunanaan media } \\
\text { elektronik }\end{array}$ \\
\hline $\begin{array}{l}\text { Kualitas pelayanan } \\
\text { A. Parasuraman, } \\
\text { Zeithaml dan bery } \\
\text { dalam Tjiptono } \\
(1998: 69)\end{array}$ & $\begin{array}{ll}\text { ukuran dari } & \text { seberapa baik } \\
\text { tingkat } & \text { pelayananyang } \\
\text { disampaikan } & \text { sesuai dengan } \\
\text { harapan pelanggan }\end{array}$ & $\begin{array}{l}\text { 1. } \begin{array}{l}\text { responsiveness terkait } \\
\text { kesiapan karyawan dalam } \\
\text { memberikan pelayanan }\end{array} \\
\text { 2. } \begin{array}{l}\text { Assurance terkait } \\
\text { kepercayaan dan }\end{array} \\
\text { keyakinan } \\
\text { 3. tangible terkait dengan } \\
\text { bukti fisik, misal: fisik } \\
\text { kartu member } \\
\text { 4. empathy terkait dengan } \\
\text { pemahaman terhadap } \\
\text { keinginan dan perhatian } \\
\text { yang diharapkan } \\
\text { pelanggan dengan } \\
\text { reliability terkait denan melayani } \\
\text { kemampuan } \\
\text { pelanggan }\end{array}$ \\
\hline $\begin{array}{lr}\text { Loyalitas } & \text { Dick } \\
\text { Basu dalam } & \text { dam } \\
\text { Obonyo (2011) }\end{array}$ & $\begin{array}{l}\text { komitmen untuk membeli } \\
\text { kembali atau mendukung } \\
\text { kembali produk atau jasa } \\
\text { yang disukai pada masa yang } \\
\text { akan }\end{array}$ & $\begin{array}{l}\text { 1. Behavioral loyalty terkait } \\
\text { frekuensi pembelian } \\
\text { 2. Attitudinal loyalty terkait } \\
\text { pembelian ulang } \\
\text { 3. Cognitive loyalty terkait } \\
\text { pemikiran pelanggan }\end{array}$ \\
\hline
\end{tabular}

\section{Teknik Pengumpulan Data}

1. Kuesioner

Dalam suatu penelitian ilmiah, metode pengumpulan data dimaksudkan untuk memperoleh bahan-bahan yang relevan, akurat, dan terpercaya (Indrianto dan Supomo, 2003). Dalam penelitian ini pengumpulan data menggunakan kuesioner atau dikenal juga dengan sebutan angket. Kuesioner merupakan teknik pengumpulan data yang dilakukan dengan cara memberi seperangkat pertanyaan tertulis kepada responden untuk diisi. Dalam kuesioner ini sendiri terbagi dalam beberapa halaman yang mewakili variabel yang ada. Pertanyaan yang terlampir dalam kuesioner ini akanmewakili tiap-tiap indikator variabel yang telah ditentukan. Pengukuran variabel sendiri akan dilakukan dengan skala Likert yang menggunakan metode scoring 
sebagai berikut : Sangat Tidak Setuju $($ STS $)=1$, Tidak Setuju $(T S)=2$, Setuju $(S)=$ 3 , Sangat Setuju $(\mathrm{SS})=4$, Sangat Setuju Sekali $(\mathrm{SSS})=5$.

2. Wawancara

Metode ini dilakukan untuk mengetahi data-data sekunder seperti profil prusahaan, gambaran umum perusahaan, daftar karyawan dan lainnya. Selain dengan melakukan penyebaran kuesioner, data-data yang terkumpul juga berasal dari riset lapangan, dimana data dapat diperoleh dengan melakukan penelitian langsung untuk mendapatkan data.

\section{Instrumen Penelitian}

Menurut pendapat Colton dan Covert (2007:5) instrumen adalah suatu alat yang digunakan untuk mengukur fenomena, merekam informasi yang ditujukan untuk penilaian dan pengambilan keputusan. "An instrument is a tool for measuring, observing, or documenting quantitative data", Instrumen adalah alat untuk mengukur, mengamati, atau mendokumentasikan data (Creswell, 2012:151). Dalam penelitian ini penulis menggunakan Instrumen penelitian menggunakan kuesioner dengan pertanyaan terbuka dan skala likert dari 1- 5.

\section{Teknik Analisis Data}

Analisis data adalah proses mencari dan menyusun secara sistematis data yang diperoleh dari hasil wawancara, catatan lapangan, dan bahan-bahan lain, sehingga dapat mudah dipahami, dan temuannya dapat diinformasikan kepada orang lain (Bogdan dalam Sugiyono, 2013:244).Teknik analisis dengan menggunakan software SMARTPLS yang terdiri dari: evaluasi measurement (outer model), inner model dan uji hipotesa.

\section{ANALISIS DATA DAN PEMBAHASAN}

Penelitian ini dilakukan untuk mengetahui Pengaruh Experiential Marketing Dan Kualitas Pelayanan Yang Dipertimbangkan Dalam Pembentukan Loyalitas Konsumen Pada Klinik Kecantikan "LBC". Variabel Experiential Marketing terdiri dari 5 indikator yaitu sense, fell, think, act, dan relate. Sedangkan pada variable kualitas pelayanan terdiri dari responsiveness, assurance, tangible, empathy, dan reliability. Pada 
variabel Loyalitas terdiri dari Behavioral loyalty, attitudinal loyality, dan cognitive loyality. Sampeldalampenelitianiniberjumlah 66 responden.

Analisis data selanjutnya adalah analisisPartial Least SquareStructural Equation Modelling (PLS SEM) untuk membuktikan apakah ada pengaruh variabel independen Experiential Marketing dan variabel kualitas pelayanan berpengaruh signifikan secara simultan (serentak) dan berpengaruh secara parsial (individu). Terhadap loyalitas responden Uji pengaruh secara simultan dalam analisis regresi dilakukan dengan menggunakan uji $\mathrm{F}$.

\section{Uji Serentak}

\section{Gambar 2 : Hasil Analisis PLS}

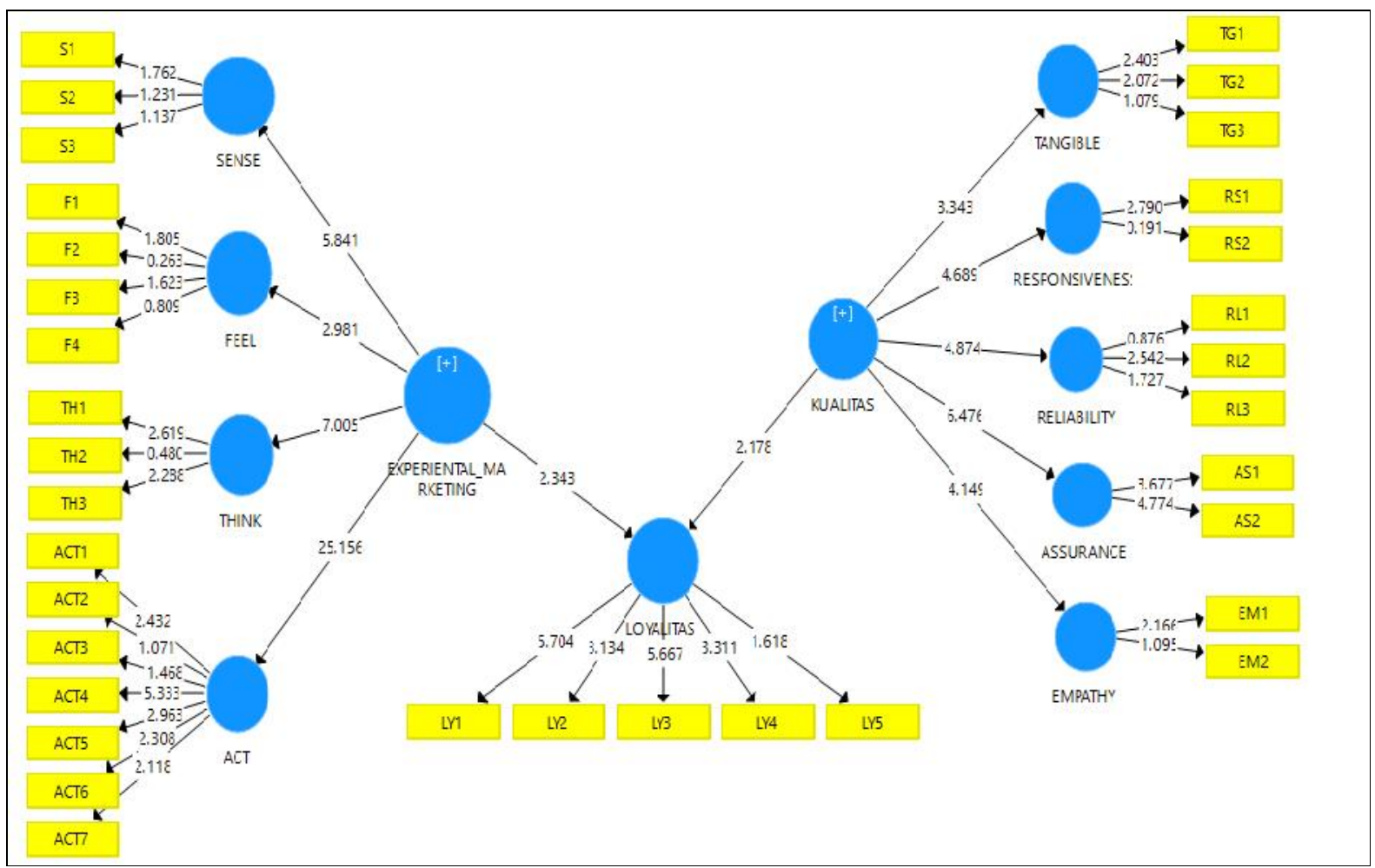

Berdasarkan hasil analisis menggunakan PLS SEM, didapatkan kesimpulan bahwa Experiental marketing dan kualitas pelayanan berpengaruh terhadap loyalitas pelanggan. Kesimpulan ini didapatkan dengan mempertimbangkan nilai t statistik kualitas dan experiental marketing masing-masing sebesar 2.343 dan 2.178dimana nilai ini lebih besar dari 1.96. Nilai t statistik untuk variabel experiental marketing lebih besar dibandingkan $\mathrm{t}$ statistik kualitas sehingga dapat disimpulkan pengaruh experiental marketing lebih besar dibandingkan kualitas. 
Tabel 3: Kontribusi setiap variabel

\begin{tabular}{|l|c|c|c|}
\hline VARIABEL & $\begin{array}{c}\text { Original Sample } \\
(\mathbf{0})\end{array}$ & $\begin{array}{c}\text { T Statistics } \\
(\mathbf{0} / \mathbf{S T E R R} \boldsymbol{)}\end{array}$ & P Values \\
\hline EXPERIENTAL_MARKETING -> ACT & 0,884 & 25,156 & 0,000 \\
\hline EXPERIENTAL_MARKETING -> FEEL & 0,454 & 2,981 & 0,003 \\
\hline $\begin{array}{l}\text { EXPERIENTAL_MARKETING -> } \\
\text { LOYALITAS }\end{array}$ & 0,407 & 2,343 & 0,020 \\
\hline EXPERIENTAL_MARKETING -> SENSE & 0,653 & 5,841 & 0,000 \\
\hline EXPERIENTAL_MARKETING -> THINK & 0,722 & 7,005 & 0,000 \\
\hline KUALITAS -> ASSURANCE & 0,722 & 6,476 & 0,000 \\
\hline KUALITAS -> EMPATHY & 0,555 & 4,149 & 0,000 \\
\hline KUALITAS -> LOYALITAS & 0,388 & 2,178 & 0,030 \\
\hline KUALITAS -> RELIABILITY & 0,632 & 4,874 & 0,000 \\
\hline KUALITAS -> RESPONSIVENESS & 0,591 & 4,689 & 0,000 \\
\hline KUALITAS -> TANGIBLE & 0,591 & 3,343 & 0,001 \\
\hline
\end{tabular}

Experiental marketing memiliki pengaruh yang signfikan terhadap loyalitas. Variabel ini disusun oleh 4 indikator yaitu ACT, FEEL, SENSE, THINK. Dari ke empat variabel ini, yang memiliki kontrobusi paling besar terhadap experiental marketing adalah ACT dengan nilai standardized koefisien sebesar 0.884 dimana nilai ini memiliki arti bahwa perubahan pada ACT akan berpengaruh terhadap perubahan experiental marketing sekitar $88.4 \%$. Nilai ini juga dapat dimaknai kenaikan pada ACT akan berdampak pada kenaikan Experiental marketing sebesar 88.4\%.

Variabel kualitas juga memiliki pengaruh yang signifikan terhadap loyalitas. Kualitas disusun oleh Assurance, Empathy, Reliability, Responsiveness, dan Tangible. Indikator yang memiliki kontribusi paling besar dalam menyusun kualitas adalah pada Assurance dengan nilai standardized koefisien sebesar 0.722. Nilai ini memilii makna bahwa perubahan pada Assurance, akan berdampak pada perubahan kualitas sebesar 72.2\%. Atau apabila ada kenaikan pada Assurance, akan dapat meningkatkan kualitas sebesar $72.2 \%$.

\section{SIMPULAN \& SARAN}

Dari hasil penelitian yang dilakukan oleh penulis, maka dapat disimpulkan :

1. Experiential Marketing mempunyai pngaruh yang signifikan terhadap loyalitas. Dari dimensi Expriential Marketing yang terdiri dari sense, feel, think, act. Menyatakan bahwa dimensi ACT merupakan dimensi yang nilai signifikasi yang paling tinggi yaitu sebesar $88.4 \%$. 
2. Kualitas pelayanan juga mempunyai pengaruh yang signifikan terhadap loyalitas. Dari indikator kualitas pelayanan yang disebut RATER Assurance memiliki pengaruh yang paling besar yaitu $72,2 \%$.

Berdasarkan kesimpulan dan hasil penelitian diatas, maka penulis dapat memberikan saran :

1. Klinik LBC dapat meningkatkan Experiential Marketing yang sudah ada dengan cara memperhatikan dimeni lain dalam rangka meningkatkan kepuasan pelanggan yang akhirnya membuat pelanggan loyal.

2. sedangkan untuk variabel kualitas pelayanan perlu ditinjau kembali indikator lain dalam variabel kualitas pelayanan yang mampu meningkatkan loyalitas konsumen.

\section{DAFTAR PUSTAKA}

A, Parasuraman. (2001). The Behaviorial Consequenses of Service Quality, Jurnal of Marketing, Vol 60.

Creswll, J., W., 2012, Research design Pendekatan kualitatif, Kuantitatif dan Mixed; Cetakan ke-2, Yogyakarta: Pustaka Pelajaran.

Colton, David dan Robert W. Covert, 2007. Designing and Constructing Instruments for Social Research and Evaluation, San Francisco: Jossey-Basse.

Dian Dharmayanti \& Reymond Setiabudi Hadiwidjaja. 2014. "Analisis hubungan experiential marketing kepuasan pelanggan, loyalitas pelanggan Starbucks Coffee di Surabaya Town Square". Jurnal Manajemen Pemasaran. Vol.2 No.2.

Http://etd.repository.ugm.ac.id/index.php?mod=download\&sub=DownloadFile\&act=vi ew\&typ=html\&id=80833\&ftyp=potongan\&potongan=S2-2014-343601chapter1.pdf

Kotler, Philip and Gary Armstrong. 2012. Prinsip-prinsip Pemasaran. Edisi 13. Jilid 1. Jakarta : Erlangga.

Kotler, Philip and Keller, Kevin Lane. (2012). Marketing Management, 14th Edition.New Jersey: Prentice Hall Published.

Lee, Ming-Shing, Hsio, Huey-Der, dan Yang, Ming-Fen. (2010). “The Study Of The Relationship Among Experiential Marketing, Kualitas pelayanan, Kepuasan pelanggan And Loyalitas". International J ournal of Organizational Innovation. Hlm. 352-378 
Ekasari, Novita. (2015). "Pengaruh Experiential Marketing terhadap loyalitas pelanggan klinik perawatan kulit natasha kota Jambi”. Jurnal Penelitian Universitas Jambi : Seri Humaniora. Volume : 17 No.2

Obonyo, Moses. (2011). "Experintial Marketing, Experiential Value, PurchaseBehavior, and Loyalitas in The Telecoms Industry." Research Dissertationfor The Award of Master of Science in Marketing. Uganda: MakerereUniversity.

Parasuraman, A., Zeithaml \& Berry. (1985). "SERVQUAL: A multiple-item scale formeasuring consumer perceptions of kualitas pelayanan." Journal ofMarketing. Vol 49 (fall 1985). Hlm 41-50.

Scmitt, Bernd. (1999). Experiential Marketing. New York: The Free Press.

Sugiyono. 2013. Metode Penelitian Pendidikan (Pendekatan Kuantitatif, Kualitatis, dam $R \& D)$. Bandung : Alfabeta. 